\title{
Efforts to Control Blood Pressure among Hypertension Patients in the Community Health Center of Sei Mencirim Working Area, Medan, Indonesia \\ Agustina Boru Gultom*, Arbani Batubara \\ Department of Nursing, Polytechnic of Health Ministry of Health, Medan, Indonesia
}

Submitted: December $7^{\text {th }}$ 2020; Revised: June $9^{\text {th }}$ 2021; Accepted: November $27^{\text {th }} 2021$

Keywords:
Blood pressure
Education
Knowledge
Progressive
$\quad$ muscle
relaxation
exercises

\begin{abstract}
Community Health Center of Sei Mencirim working area had various health problems, one of which was hypertension. There were 2 villages have many cases of hypertension, including Sei Beras Sekata and Sei Mencirim Village. Lifestyle interventions can reduce blood pressure and other interventions such as pharmacology. Lifestyle interventions include dietary behavior, weight management, regular physical exercise and, stress management through progressive muscle relaxation exercises. Participants were 45 people with hypertension, divided into 2 groups consisting of 22 participants from Sei Beras Sekata and 23 participants from Sei Mencirim Village. The team has given educational intervention about efforts to control blood pressure and progressive muscle relaxation exercises by explaining, asking questions, giving examples, and inviting participants to do it. Measurement of knowledge used a questionnaire and, blood pressure used an Omron digital sphygmomanometer. Implementation activities included pretest, intervention, and post-test were given on the same day. This activity was carried out in September 2020. The results of the intervention showed an increase in knowledge of 1.09, a decrease in systolic blood pressure of 9.42 $\mathrm{mmHg}$ and, a diastolic score of $4.64 \mathrm{mmHg}$. Education with progressive muscle relaxation exercises has increased knowledge scores, decreased systolic and diastolic blood pressure scores.
\end{abstract}

\section{INTRODUCTION}

Hypertension is a high blood pressure disease, which still becomes a concern in many parts of the world, including Indonesia. This disease is characterized by having a systolic blood pressure of $140 \mathrm{mmHg}$ or higher and a diastolic blood pressure of $90 \mathrm{mmHg}$ or higher (Williams et al., 2018).

It is the most significant trigger factor of heart and blood vessel problems. If hypertension is not properly controlled, the increase in blood pressure can cause problems in the brain, heart, kidney, memory, and vision, resulting in human suffer, huge economic burdens, and a severe increase in the health care system (WHO, 2014).

The prevalence of hypertension medication use has decreased from $9.5 \%$ in 2013 to $8.8 \%$ in 2018 .
However, based on the hypertension measurement results, it has increased in the last five years. According to the results, it has risen from $25.8 \%$ in 2013 to $34.1 \%$ in 2018 (The Ministry of Health of the Republic of Indonesia, 2018).

A scientific study found that lowering blood pressure has societal and individual advantages. As an illustration, the efforts to reduce systolic blood pressure by $10 \mathrm{mmHg}$ will be associated with a $22 \%$ reduction in coronary heart disease, a $41 \%$ reduction in strokes, and a decrease in cardiac metabolic mortality (WHO, 2014).

Intervention through lifestyle modification has a greater chance of improving blood pressure control and even minimizing the need for pharmacological agent use (James et al., 2014). These lifestyle behaviors

ISSN 2460-9447 (print), ISSN 2541-5883 (online)

*Corresponding author: Agustina Boru Gultom

Department of Nursing, Polytechnic of Health Ministry of Health, Jl.Bunga Ncole No.95 Kemenangan Tani, Medan Tuntungan, Medan, North Sumatera 20136, Indonesia

Email: agnagultom682@gmail.com 
include diet, weight management, regular physical exercise, and stress control (Gupta \& Guptha, 2010).

There are several efforts of stress management to control blood pressure, one of which is progressive muscle relaxation. This intervention is one type of relaxation technique that combines deep breathing exercises with a series of muscles contraction and relaxation (Setyoadi \& Kushariyadi, 2011). This technique has a strong clinical record in dealing with stress (Mackereth \& Tomlinson, 2010). Progressive muscle relaxation is more effective than deep breathing relaxation in controlling blood pressure (Manoppo \& Anderson, 2019). Several studies have demonstrated that progressive muscle relaxation can lower hypertensive patients' blood pressure within four weeks (Siregar \& Gultom, 2018; Hasandokht et al., 2015). In short, progressive muscle relaxation can instantly lower blood pressure (Shinde et al., 2013; Sheu et al., 2003).

Based on the results of a preliminary survey with health workers at the Community Health Center of Sei Mencirim, various health issues were discovered, including ISPA, Hypertension, and Diabetes Mellitus (DM). In 2019, the Community Health Center of Sei Mencirim received an average of 70 hypertension patient visits per month. A survey was also conducted with health workers, and it was found that two villages within the working area of the Community Health Center of Sei Mencirim have some people who suffer hypertension. Some patients who have been treated at the Community Health Center have taken medicine, as well as those who have never gone there. Some people have taken antihypertensive medicines, but they still have high blood pressure. Meanwhile, some others have never been treated and are unaware that they have increased blood pressure. Stressor tension in daily life, including stress at home and at work, is one of the factors that impacted and contributed to the increase in blood pressure of the people in those two villages.

\section{METHOD}

Community service activities were conducted in three stages, consisting of preparation, intervention, and evaluation.

\subsection{Preparation}

The community service team conducted an initial survey in this stage, and it was found that one of the health problems in the Community Health Center of Sei Mencirim working area was hypertension with an average visit of 70 people per month. The two areas in the that had hypertension issues were Sei Beras Sekata and Sei Mencirim Village. The team had also approached the managers of the Community Health Center of Sei Mencirim in hope of obtaining data and planning the next steps. After that, the community service team planned the things needed, such as the facilities and materials utilized to do the intervention, as well as arranging activity permissions. The participants chosen were the health workers who became the partners of community service team. Participants had to be above the age of 18 , had been diagnosed with hypertension by a health professional, had never taken antihypertensive medicines before, and their body temperature must be less than 37 degrees Celsius during the activity.

\subsection{Intervention}

This stage began by presenting a health protocol due to COVID-19 pandemic situation. The protocols included measuring temperature with an infrared thermometer, creating small groups, keeping their distances, as well as administering antiseptic fluids and performing 7 steps on how to wash hands. The pre-test for measuring blood pressure was conducted using Omron Model HEM-7130 digital sphygmomanometer manufactured by Omron Healthcare Manufacturing Vietnam Co. Ltd in Binh Duong Province, Vietnam. During the pre-test, the team used a questionnaire to measure participants' knowledge about the efforts in controlling blood pressure.

The community service team used lecturing method, questions and answers, as well as demonstrations and re-demonstrations of progressive muscle relaxation exercises in one meeting. These forms of activities were conducted as an education about blood pressure control and progressive muscle relaxation exercises.

The target in this activity was 45 respondents with hypertension who were divided into two groups of 22 participants from Sei Beras Sekata Village and 23 participants from Sei Mencirim Village. Due to the Covid-19 pandemic situation, each village group has been subdivided into small groups of 5-6 participants for each activity.

The media used in this activity were educational modules about some efforts to control blood pressure and the procedures of progressive muscle relaxation exercises. This module contains two themes that participants can apply during the intervention or at home. The first theme on hypertension description includes the definition, causes, signs and symptoms, diagnosis, complications, and hypertension treatment planning. Meanwhile, the second theme consists of the notion, impact, preparation, and progressive muscle relaxation procedures. The team also used other media, such as OMRON digital blood pressure device, COVID-19 prevention supplies (masks, gloves, hand sanitizers, and one type of infrared thermometer), as well as a questionnaire for filling out characteristics and participant's knowledge. 


\subsection{Evaluation}

This stage was conducted after the intervention. The team conducted an evaluation or post-test using a questionnaire and the same instruments in each location, both in Sei Beras Sekata Village and in Sei Mencirim Village. It was completed in a short time immediately after the intervention was given. The team tested the participants' knowledge about blood pressure control efforts and progressive muscle relaxation using a questionnaire and blood pressure devices. Both of these instruments were the same as the ones used for the pre-test.

\section{RESULT AND DISCUSSION}

Community services have been conducted on two groups of hypertension patients: group one in Sei Beras Sekata Village with 22 respondents and group two in Sei Mencirim Village with 23 respondents. Each respondent has undergone a pre-test, intervention, and post-test. The results of activities can be seen in Table 1, Table 2, and Figure 1.

Table 1. Respondent characteristics

\begin{tabular}{|c|c|c|}
\hline Variable & Frequency & Percentage (\%) \\
\hline \multicolumn{3}{|l|}{ Age } \\
\hline $35-44$ & 5 & 11.1 \\
\hline $45-59$ & 21 & 46.7 \\
\hline $60-74$ & 14 & 31.1 \\
\hline $75-90$ & 4 & 8.9 \\
\hline$>90$ & 1 & 2.2 \\
\hline \multicolumn{3}{|l|}{ Sex } \\
\hline Male & 6 & 13.3 \\
\hline Female & 39 & 86.7 \\
\hline \multicolumn{3}{|l|}{ Education } \\
\hline Primary school & 17 & 37.8 \\
\hline Junior high & 5 & 11.1 \\
\hline school & 19 & 42.2 \\
\hline $\begin{array}{c}\text { Senior high } \\
\text { school }\end{array}$ & 4 & 8.9 \\
\hline \multicolumn{3}{|l|}{ Collage } \\
\hline \multicolumn{3}{|l|}{ Marital Status } \\
\hline Single & 1 & 2.2 \\
\hline Married & 34 & 73.6 \\
\hline Widower/ widow & 10 & 22.2 \\
\hline \multicolumn{3}{|l|}{ Income. IDR } \\
\hline $\begin{array}{r}>2,132,188- \\
4,500,000\end{array}$ & 12 & 26.7 \\
\hline$\leq 2,132,188$ & 33 & 73.3 \\
\hline \multicolumn{3}{|l|}{ Profession } \\
\hline Housewife & 29 & 64.4 \\
\hline Private & 2 & 4.4 \\
\hline employees & 1 & 2.2 \\
\hline Entrepreneur & 6 & 13.3 \\
\hline Retired & 7 & 15.6 \\
\hline Others & & \\
\hline \multicolumn{3}{|l|}{ Duration of } \\
\hline hypertension, year & & \\
\hline$<1$ & 30 & 66.7 \\
\hline$\geq 1-<5$ & 10 & 22.2 \\
\hline$\geq 5-<10$ & 1 & 2.2 \\
\hline$\geq 10-<15$ & 3 & 6.7 \\
\hline$\geq 20$ & 1 & 2.2 \\
\hline
\end{tabular}

Table 2 shows blood pressure and knowledge before and after education on blood pressure control and progressive muscle relaxation exercises, as well as differences in the scores. Based on Table 2, it can be seen that the average systolic score before the intervention was $(154.16 \pm 15.21) \mathrm{mmHg}$ while after the intervention was $(144.73 \pm 14.69) \mathrm{mmHg}$, the average diastolic score before the intervention was $(95.76 \pm 10.16)$ while after the intervention was $(91.11 \pm 10.85) \mathrm{mmHg}$, and the average knowledge score before the intervention was $(6.11 \pm 1.48)$ while after the intervention was $(7.20 \pm 0.81)$.

Table 2. Pre and post-intervention blood pressure and knowledge score

\begin{tabular}{|c|c|c|c|c|c|}
\hline & Min & Max & Mean & \pm SD & $\begin{array}{c}\text { Mean } \\
\text { diff }\end{array}$ \\
\hline $\begin{array}{l}\text { Pre- } \\
\text { intervention } \\
\text { systolic BP, } \\
\text { mmHg }\end{array}$ & 140 & 212 & 154.16 & 15.21 & \multirow[b]{2}{*}{0.42} \\
\hline $\begin{array}{l}\text { Post- } \\
\text { intervention } \\
\text { systolic BP, } \\
\text { mmHg }\end{array}$ & 122 & 203 & 144.73 & 14.69 & \\
\hline $\begin{array}{l}\text { Pre- } \\
\text { intervention } \\
\text { diastolic } \\
\mathrm{BP}, \mathrm{mmHg}\end{array}$ & 73 & 124 & 95.76 & 10.16 & \multirow[b]{2}{*}{4.62} \\
\hline $\begin{array}{l}\text { Post- } \\
\text { intervention } \\
\text { diastolic } \\
\mathrm{BP}, \mathrm{mmHg}\end{array}$ & 70 & 119 & 91.11 & 1.85 & \\
\hline $\begin{array}{l}\text { Pre- } \\
\text { intervention } \\
\text { knowledge } \\
\text { score }\end{array}$ & 1 & 8 & 6.11 & 1.48 & \multirow{2}{*}{-1.09} \\
\hline $\begin{array}{l}\text { Post- } \\
\text { intervention } \\
\text { knowledge } \\
\text { score }\end{array}$ & 5 & 9 & 7.20 & 0.81 & \\
\hline
\end{tabular}

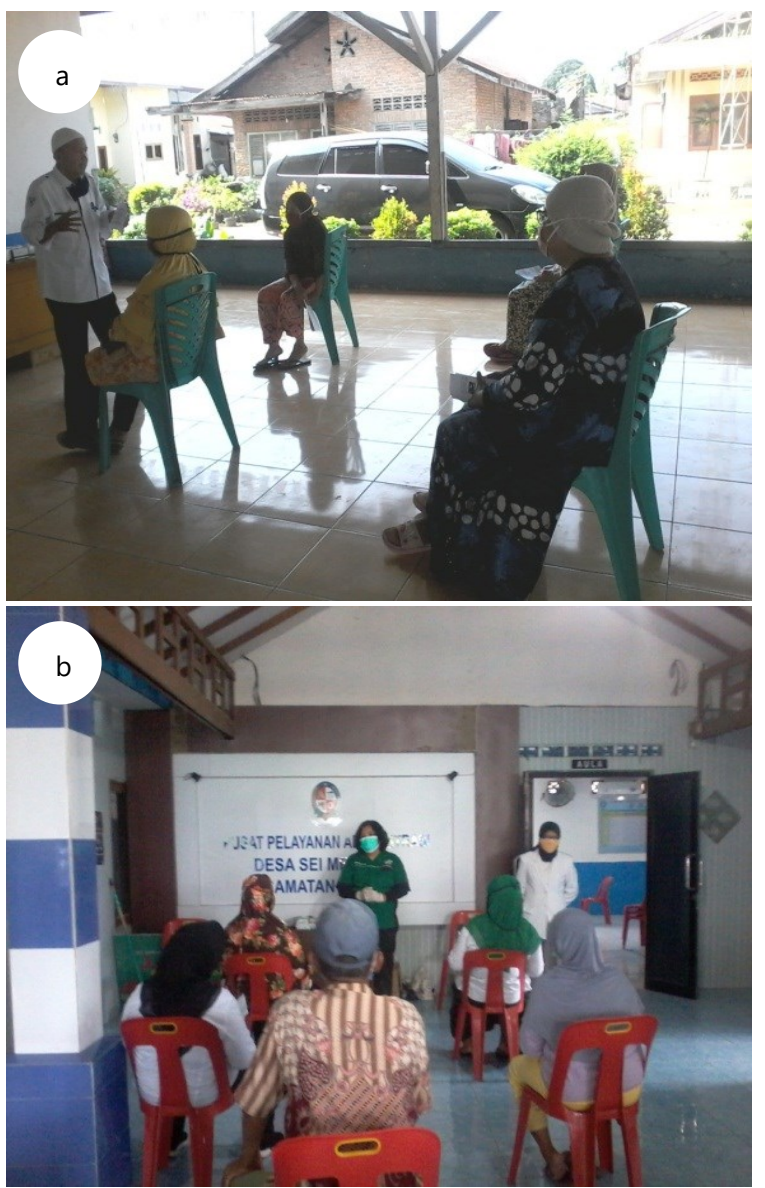

Figure 1. Community service activities of the Community Health Center of Sei Mencirim Working Area a) Activities in Sei Beras Sekata Village where the team was explaining about 
hypertension; b\} Activities in Sei Mencirim Village where the team was explaining about progressive muscle relaxation

This community service aims for participants to experience the decrease in blood pressure and increase in knowledge after receiving education on blood pressure control and progressive muscle relaxation exercises. The results of community service revealed that education blood pressure control and progressive muscle relaxation exercises had a significant impact on the participants.

The results of this community service showed that the education on blood pressure control and progressive muscle relaxation exercises gave an opportunity for the participants to control their systolic blood pressure for a short time because the post-education assessment was conducted on the same day. There were several studies related to the results of community service that have been conducted (Gultom \& Indrawati 2020; Shinde et al., 2013; Sheu et al., 2003).

The difference in diastolic blood pressure after and before the intervention conformed to the established assessment criteria, which stated that after receiving the education, the participants would have a $2 \mathrm{mmHg}$ decrease in diastolic blood pressure. It can be concluded that education on blood pressure control and progressive muscle relaxation exercises give good opportunities for hypertensive participants to control their diastolic blood pressure in a short period of time. Several studies related to this result have been conducted (Gultom \& Indrawati 2020; Shinde et al., 2013; Sheu et al., 2003).

The difference in the mean of the participants' knowledge after receiving education on blood pressure control and progressive muscle relaxation exercises compared to the mean of knowledge before education revealed a 1.09 rise in the score. This is relevant to the evaluation criteria that have caused the knowledge score increased by $10 \%$ from the average score before the education. The average knowledge score before the education was 6.11, so it was expected that the minimum knowledge score increase would be 6.72 . After the education, the results showed a score of 7.2.

This community service, which taking the form of education on blood pressure control and progressive muscle relaxation exercises, has contributed in increasing participants' knowledge in a relatively short time because it was conducted after the implementation of education. Another study noted the effect of health education on changes in public knowledge about hypertension as controlling factors that can or cannot be managed (Nelwan, 2019). Each participant received only one session of education on blood pressure control and progressive muscle relaxation.

The team had distributed materials in the form of modules that can be read by participants to attach the activities obtained after the education. It aims to improve the participants' memory. In addition, the participants are expected to apply the knowledge and skills in their daily lives.

\section{CONCLUSION}

Implementation of education about efforts to control blood pressure and progressive muscle relaxation exercises in hypertensive patients contributed to increase knowledge and decrease blood pressure. It is recommended that this training in the form education can be an alternative nursing intervention to control blood pressure in hypertensive patients. Hypertensive patients who are already taking antihypertensive drugs may experience a decrease in blood pressure but may or may not, if a healthy lifestyle in not supported. One of the healthy lifestyle modification interventions in hypertensive patients is through proper and regular progressive muscle relaxation exercises.

\section{ACKNOWLEDGMENT}

The community service was sponsored by Polytechnic of Health Ministry of Health, Medan, North Sumatera, Indonesia. We would like to thank to health officers at Community Health Center of Sei Mencirim who have collaborated in carrying out this community service.

\section{REFERENCES}

Gultom,A,B.Indrawati. (2020). Relaksasi Otot Progresif Terhadap Tekanan Darah Pada Pasien Hipertensi Dengan Waktu Yang Cepat. Jurnal Ilmiah PANNMED (Pharmacist, Analyst, Nurse, Nutrition, Midwivery, Environment, Dentist), 15(1), 52-59. https://doi.org/10.36911/pannmed.v15i1.649

Gupta, R., \& Guptha, S. (2010). Strategies for initial management of hypertension. Indian Journal of Medical Research, 132(5), 531-542. https://www.ncbi.nlm.nih.gov/pmc/articles/PM C3028941/

Hasandokht, T., Farajzadegan, Z., Siadat, Z. D., Paknahad, Z., \& Rajati, F. (2015). Lifestyle interventions for hypertension treatment among iranian women in primary health-care settings: Results of a randomized controlled trial. Journal of Research in Medical Sciences.

James, P. A., Oparil, S., Carter, B. L., Cushman, W. C., Dennison-Himmelfarb, C., Handler, J., Lackland, D. T., LeFevre, M. L., MacKenzie, T. D., Ogedegbe, O., Smith, S. C., Svetkey, L. P., Taler, S. J., Townsend, R. R., Wright, J. T., Narva, A. S., \& Ortiz, E. (2014). 2014 Evidencebased guideline for the management of high blood pressure in adults: Report from the panel members appointed to the Eighth Joint National Committee (JNC 8). In JAMA - Journal of the American Medical Association. https://doi.org/10.1001/jama.2013.284427 
Kementerian Kesehatan RI. (2018). Laporan Nasional Riskesdas 2018.

Mackereth,P,A.,Tomlinson,L. (2010). Progressive Muscle Relaxation: a remarkable tool for therapists and patients. In B. Cawthorn,A.,Mackereth, $\mathrm{P}$ (Ed.), Integrative Hypnotherapy. Complementary Approaches In Clinical Care (pp. 82-96). Churchill Livingstone Elsevier.

Manoppo,A,J.,Anderson,E. (2019). Effect of Progressive Muscle Relaxation and Slow Deep Breathing on Blood Pressure and Heart Rate on Hypertensive Clients. International Conference on Healthcare and Technology, 497-509. https://doi.org/https://doi.org/10.18502/kls.v4i1 3.5281

Nelwan, J. E. (2019). Pengaruh Penyuluhan Kesehatan Terhadap PerPubahan Pengetahuan Masyarakat Tentang Hipertensi Di Kota Manado. Journal $P H W B$.

Setyoadi., Kushariyadi. (2011). Terapi Modalitas Keperawatan Pada Klien Psikogeriatrik. Salemba Medika.

Sheu, S., Irvin, B. L., Lin, H. S., \& Mar, C. L. (2003). Effects of Progressive Muscle Relaxation on Blood Pressure and Psychosocial Status for Clients with Essential Hypertension in Taiwan. Holistic Nursing Practice. https://doi.org/10.1097/00004650-20030100000009

Shinde, N., Shinde, K., Khatri, S., \& Hande, D. (2013). Immediate Effect of Jacobson's Progressive Muscular Relaxation in Hypertension. Indian Journal of Physiotherapy and Occupational Therapy - An International Journal. https://doi.org/10.5958/j.0973-5674.7.3.098

Siregar,A,H.,Gultom, A, B. (2018). The influence of progressive muscle relaxation on stress, blood pressure, and quality of life in hypertension patients in the working area of Muliorejo Puskesmas, deli Serdang regency. International Journal of Advanced Nursing Studies, 7(1), 3943. https://doi.org/10.14419/ijans.v7i1.8931

WHO. (2014). Global status report on NCDs 2014. In WHO.

Williams, B., Mancia, G., Spiering, W., Agabiti Rosei, E., Azizi, M., Burnier, M., Clement, D. L., Coca, A., de Simone, G., Dominiczak, A., Kahan, T., Mahfoud, F., Redon, J., Ruilope, L., Zanchetti, A., Kerins, M., Kjeldsen, S. E., Kreutz, R., Laurent, S., Lip, G., ... ESC Scientific Document Group (2018). 2018 ESC/ESH Guidelines for the management of arterial hypertension. European heart journal, 39(33), 3021-3104. https://doi.org/10.1093/eurheartj/ehy339 